Marquette University

e-Publications@Marquette

6-1-2003

\title{
Digital Divide and Purchase Intention: Why Demographic Psychology Matters
}

Syed H. Akhter

Marquette University, syed.akhter@marquette.edu

Accepted version. Journal of Economic Psychology, Vol. 24, No. 3 (June 2003): 321-327. DOI. NOTICE: this is the author's version of a work that was accepted for publication in Journal of Economic Psychology. Changes resulting from the publishing process, such as peer review, editing, corrections, structural formatting, and other quality control mechanisms may not be reflected in this document. Changes may have been made to this work since it was submitted for publication. A definitive version was subsequently published in Journal of Economic Psychology, VOL 24, ISSUE 3, (June 2003) DOI. 


\section{Digital Divide and Purchase Intention: Why Demographic Psychology Matters}

By Syed H. Akhter

The author examines the issue of digital divide from a demographic perspective. The influence of gender, age, education, and income on the likelihood to purchase over the Internet is empirically examined. Hypotheses are framed in the context of psychological correlates of the demographic variables. Findings show that these variables significantly influence the likelihood to purchase over the Internet and can be used to profile, segment, and target markets and develop public policies to bridge the digital divide.

In its recent report, Falling Through the Net: Toward the Digital Inclusion, The Department of Commerce concluded that digital inclusion in the US is rapidly increasing and that groups that have traditionally been digital "have-nots" are now making dramatic gains (www.ntia.doc.gov 2000). However, the report also drew attention to the noticeable divide that continues to persist between people with different demographic characteristics such as age, income, education, ethnicity, and marital status. Although the issue of the digital divide has received extensive coverage, reports and discussions generally highlight only one aspect of the divide; the number of people who are digitally connected and have access to the Internet. What has received inadequate attention is the divide that separates people based on how they use the Internet. From both business and public policy perspectives, this divide has far reaching consequences.

The introduction of the Internet into our social system has raised theoretical questions and public policy concerns. One substantive theoretical question relates to factors that explain different uses of the Internet. For example, why are some people more likely to use the Internet for making a purchase and some less? And from a public policy perspective it would be valuable to identify people who are less likely to use the Internet.

Taking an interdisciplinary approach, this paper explores relations between demographic variables and the likelihood of making a purchase over the Internet. Understanding these relations can facilitate the development of consumer profiles that can be used to segment and target customers. Similarly, these profiles can provide public policy officials with the information they need to reach people who can benefit from policies that encourage the use of the Internet. Thus, the objective of this paper is to empirically test relations between demographic characteristics and the likelihood of purchasing over the Internet. 


\section{Introduction}

Building on the works of Robertson (1967), Bass (1969), and Rogers (1983, 1995), scholars have attempted to understand the influence of consumer characteristics on the adoption of new products. Two types of characteristics commonly studied are demographic characteristics (LaBay \& Kinnear, 1981; Marks \& Hughes, 1976) and personality traits (Brittingham, Goff, \& Haring, 1989; Ehrlich \& Lee, 1969; Gatignon \& Robertson, 1989). Together these studies have enhanced our understanding of the product adoption process, especially of single-use products.

With the ongoing crisis in the dot-com business-to-consumer sector, the understanding of relations between demographic characteristics and the use of the Internet, a multiple-use product, is becoming increasingly important. Although there are many descriptive studies of Internet users (Ernst \& Young, 2000; Smith \& Clurman, 1997), there is a lack of empirical studies focusing on Internet shopping (Particelli \& Angela da Rocha, 2001). The study of the Internet is important because, compared to other technological innovations, such as radios, TVs, and cellular phones, the Internet is different both in terms of the demand it places on users' cognition and willingness to learn to use the product. In particular, the multiple use of the Internet requires an understanding of the technology, the hardware as well as the software. The Internet is a multi-function, discontinuous innovation, and determining the influence of demographics on the likelihood of using the Internet to make a purchase becomes worthy of research.

\section{Research context and hypotheses}

Although the issue of digital divide between different ethnic groups has drawn considerable attention, the premise of this paper is that digital divide is not only an inter-ethnic but also an intra-ethnic phenomenon. That is, digital divide will exist not only between different ethnic groups, but also within a specific ethnic group, such as whites or blacks, because of demographic differences within the group. This study explores the issue of digital divide among whites. Four demographic variables (gender, age, education, and income) are used to explain variation in the likelihood of using the Internet for making a purchase. The hypotheses related to these variables are presented next.

\subsection{Gender and purchase intention}

Gender differences in attitudes and behavior have been extensively researched in general psychology and the business literature. Studies show that women are more motivated by non-economic goals than men (Chaganti, 1986) and have a smaller threshold for business 
expansion than men (Cliff, 1998). Studies in finance also show that men engage in risk taking behavior more than women (Bajtelsmit \& VanDerhei, 1997; Hinz, McCarthy, \& Turner, 1997), show more overconfidence (Lundeberg, Fox, \& Puncochar, 1994), and rely on themselves more for making decisions (Lewellen, Lease, \& Schlarbaum, 1977). In an extensive review of recent literature, Eagly (1995, p. 148) concludes that psychologists "are in general agreement that their meta-analytic findings yield evidence of differences". And Powell and Ansic (1997, p. 607) conclude that the "one gender difference which is persistently found in both the general and business specific literature is a lower preference for risk amongst females". These gender-related attitudinal and behavioral characteristics suggest that the likelihood to purchase over the Internet will also vary among men and women, because buying over the Internet is different from buying at a traditional retail outlet in terms of associated risk, security, and privacy of information given. We, therefore, propose the following hypothesis:

H1: Men will be more likely to purchase over the Internet than women.

\subsection{Age and purchase intention}

Age affects people's attitudes and behavior (Beatty \& Smith, 1987; Klippel \& Sweeny, 1974). As people age, they show greater reluctance to adopt new technologies (Gilly \& Ziethaml, 1985; Phillips \& Sternthal, 1977), become more cautious, and seek greater certainty in their decisions (Botwinick, 1973), thus increasing their commitment to their existing behavioral patterns. The elderly also exhibit more negative perceptions toward new technologies (Pommer, Berkowitz, \& Walton, 1980). As such, they have been shown to be less likely to use credit cards (Porter, Swerdlow, \& Staples, 1979) and automated teller machines (Bednar, Reeves, \& Lawrence, 1995). The use of the Internet for making a purchase will require reducing commitment to existing patterns of behavior and a change in attitude. As such, we propose the following hypothesis:

H2: The likelihood to purchase over the Internet will decrease with age.

\subsection{Education and purchase intention}

Education affects information acquisition and product evaluation strategies of consumers. Research in marketing shows that educated consumers are more likely to engage in extended search (Beatty \& Smith, 1987; Doti \& Sharir, 1981; Engel, Kollat, \& Blackwell, 1973) and use product related information (Nagya, Lipinski, \& Savur, 1998). Existing studies also show that less-educated consumers do not have the same level of brand and price information as 
better-educated consumers (Granger \& Billson, 1972; Russo, Dreiser, \& Miyashita, 1975), and more educated consumers exhibit a greater evaluation propensity (Murthi \& Srinivassan, 1999). Based on this evidence, we can conclude that people with higher education will be more informed about the use of the Internet for making purchases. We, therefore, propose the following hypothesis:

H3: The likelihood to purchase over the Internet will increase with education.

\subsection{Income and purchase intention}

Income is closely related with the opportunity cost of time. As income increases, the perception of the value of time changes. Economic studies indicate that high-income consumers will exhibit a high valuation of time (Goldman \& Johansson, 1978; Stigler, 1961). The opportunity cost of time associated with making a purchase over the Internet may thus influence the intention to purchase over the Internet. As such, people with a higher income will prefer the Internet because of the time saving feature of the Internet. We, therefore, propose the following hypothesis:

$\mathrm{H} 4$ : The likelihood to purchase over the Internet will increase with income.

\section{Method}

\subsection{Questionnaire and sample}

A survey questionnaire was mailed in two waves to 5349 subscribers and single ticket buyers of a major symphony orchestra in the Midwest. The questionnaire went through the recommended iterations before the final version was developed. The total number of responses received was 3087 . Of the total respondents, 95.4\% identified themselves as Caucasian. Of the 3087 responses received, 1794 were used in the analysis, giving an overall response rate of $33.5 \%$. The rest, in addition to non-Caucasian sample, could not be used in the analysis either because of missing values or because the respondents gave their responses jointly as a family (both male and female).

\subsection{Variables}

The dependent variable measured the likelihood of purchasing symphony tickets over the Internet. A Likert-type scale, anchored by "definitely would" and "definitely would not," was used. The four independent variables are gender (male or female), age (under 25, 25-34, 35-49, 
50-54, 55-64, 65-74, 75-85, and over 85), education (HS graduate or less, some college or tech school, associate's degree, bachelor's degree, master's degree or LLD, PhD or MD), and income (less than $\$ 30,000$, \$30,000-49,999, \$50,000-69,999, \$70,000-89,999, $\$ 90,000-124,999, \$ 125,000-149,999, \$ 150,000-199,999, \$ 200,000-249,999, \$ 250,000$ or more).

\section{Model and findings}

Multiple regression analysis was used to test the hypotheses in this study. Based on the hypotheses $(\mathrm{H} 1, \mathrm{H} 2, \mathrm{H} 3$, and $\mathrm{H} 4)$, the following expectations regarding the sign of the regression coefficients was developed: sex (+), age (-), education (+), and income (+). Table 1 provides results of cross-section regression estimates for purchase intention. Gender, age, and income coefficients are in the expected direction and significant at $(p<0: 01)$ level; and the education coefficient is in the expected direction and significant at $(p<0: 10)$ level (see Table 1).

\section{Implications and research directions}

The issue of digital divide has emerged as one of the critical issues facing businesses and public policy makers. Although the current debates on digital divide focus on the issue of accessibility, the premise of this paper is that the divide focusing on the use of the Internet will become more critical in the future. This paper examined the phenomenon of digital divide from an intra-ethnic perspective. Findings from this study suggest that demographic characteristics and their psychological correlates significantly influence the likelihood of purchasing tickets over the Internet.

Overall, the results suggest that males in contrast to females, younger people in contrast to older, more educated in contrast to less educated, and wealthier people in contrast to less wealthy are more likely to use the Internet for purchasing symphony tickets. This profile can be used by marketers to segment and target their customers, and by public policy officials to reach people and encourage Internet usage. A limitation of this study is that the respondents are all symphony goers and thus may not be representative of the overall population. The digital divide will continue to be an important issue for our society. It would thus be theoretically meaningful to see if the relationships obtained in this study generalize to other ethnic groups. As the Internet becomes an integral part of our lives, future studies can explore the social effects of the use of the Internet, and the different reasons for which people use the Internet. 


\section{References}

Bass, F. (1969). A new product growth model for consumer durables. Management Science, 15(January), 215-227.

Bajtelsmit, V. L., \& VanDerhei, J. L. (1997). Risk aversion and pension investment choices. In M. S. Gordon, O. S. Mitchell, \& M. M. Twinney (Eds.), Positioning pensions for the twenty-first century (pp. 45-66). Philadelphia: University of Pennsylvania Press.

Beatty, S., \& Smith, S. (1987). External search effort: An investigation across several product categories. Journal of Consumer Research, 14(June), 83-95.

Bednar, D. A., Reeves, C. A., \& Lawrence, R. C. (1995). The role of technology in banking: Listen to the customer. Journal of Retail Banking Services, 17, 35-41.

Botwinick, J. (1973). Aging and behavior. New York: Springer.

Brittingham, R. L., Goff, B. G., \& Haring, R. C. (1989). Refinanciers and non-refinanciers: A comparative analysis. Journal of Retail Banking, 11(Spring), 27-34.

Chaganti, R. (1986). Management in women-owned enterprises. Journal of Small Business Management, 24(4), 40-53.

Cliff, J. E. (1998). Does one size fit all? Exploring the relationship between attitudes towards growth, gender, and business size. Journal of Business Venturing, 13(6), 523-542.

Doti, J. L., \& Sharir, S. (1981). Households' grocery shopping behavior in the short run: Theory and evidence. Economic Inquiry, 19(April), 196-208.

Eagly, A. (1995). The science and politics of comparing women and men. American Psychologist, 50(3), 145-158.

Ehrlich, H. J., \& Lee, D. (1969). Dogmatism, learning and resistance to change: A review and a new paradigm. Psychological Bulletin, 71(April), 249-260.

Engel, J. F., Kollat, E. T., \& Blackwell, R. D. (1973). Consumer behavior (2nd ed.). New York: Holt, Rinehart, \& Winston.

Ernst, \& Young, (2000). Global online retailing: An Ernst and Young special report, Section 2. Stores, 12(January), 12.

Gatignon, H., \& Robertson, T. S. (1989). Technology diffusion: An empirical test of competitive effects. Journal of Marketing, 53(January), 35-49.

Gilly, M. C., \& Ziethaml, V. A. (1985). The elderly consumer and adoption of technologies. Journal of Consumer Research, 12(4), 353-357.

Goldman, A., \& Johansson, J. K. (1978). Determinants of search for lower prices: An empirical assessment of the economics of information theory. Journal of Consumer Research, 5(December), 176-186. 
Granger, C. W., \& Billson, A. (1972). Consumers' attitudes toward package size and price. Journal of Marketing Research, 9(August), 239-248.

Hinz, R. P., McCarthy, D. D., \& Turner, J. A. (1997). Are women more conservative investors? Gender differences in participant directed pension investments. In M. S. Gordon, O. S. Mitchell, \& M. M. Twinney (Eds.), Positioning pensions for the twenty-first century (pp. 91-103). Philadelphia: University of Pennsylvania Press.

Klippel, R. E., \& Sweeny, T. W. (1974). The use of information sources by the aged consumer. The Gerontologist, 14(2), 163-166.

LaBay, D. G., \& Kinnear, T. C. (1981). Exploring the consumer decision process in the adoption of solar energy systems. Journal of Consumer Research, 8(December), 271-278.

Lewellen, W. G., Lease, R. C., \& Schlarbaum, G. G. (1977). Patterns of investing strategy and behavior among individual investors. Journal of Business, 50, 296-333.

Lundeberg, M. A., Fox, P., \& Puncochar, (1994). Highly confident but wrong: Gender differences and similarities in confidence judgments. Journal of Educational Psychology, 86, 114-121.

Marks, R. B., \& Hughes, R. E. (1976). The consumer innovators: Identifying the profile of the earliest adopters of community antenna television. In K. L. Bernhardt (Ed.), Proceedings of the American marketing educators conference, series no. 39 (pp. 568-571).

Murthi, B. P. S., \& Srinivassan, K. (1999). Consumers' extent of evaluation in brand choice. The Journal of Business, 72(2), 229-256.

Nagya, R., Lipinski, D., \& Savur, N. (1998). Consumers' use of nutritional label while food shopping at home. The Journal of Consumer Affairs, 32, 106-120.

Particelli, F., \& Angela da Rocha, A. (2001). Early adopters of the virtual supermarket a study in Brazil. In G. Marshall \& S. Grove (Eds.), Enhancing Knowledge Development in Marketing. 2001 AMA Educators' Proceedings (Vol. 12, pp. 13-19).

Phillips, L. W., \& Sternthal, B. (1977). Age differences in information processing: An assessment of shopper response to technological change. Journal of Marketing Research, 14(4), 444-457.

Pommer, M. D., Berkowitz, E. N., \& Walton, J. R. (1980). UPC scanning: An assessment of shopper response to technological changes. Journal of Retailing, 56(2), 25-44.

Porter, T. C., Swerdlow, R. A., \& Staples, W. A. (1979). Who uses bank credit cards. Business Horizon, 22(February), 75-83.

Powell, M., \& Ansic, D. (1997). Gender differences in risk behavior in financial decision-making: An experimental analysis. Journal of Economic Psychology, 18, 605-628. 
Robertson, T. S. (1967). The process of innovation and the diffusion of innovation. Journal of Marketing, 31(January), 14-19.

Rogers, E. (1983). Diffusion of innovation (3rd ed.). New York: The Free Press.

Rogers, E. (1995). Diffusion of innovation (4th ed.). New York: The Free Press.

Russo, E. J., Dreiser, G., \& Miyashita, S. (1975). An effective display of unit price information. Journal of Marketing, 39(April), 11-19.

Smith, J. W., \& Clurman, A. (1997). Rocking the ages: The Yankelovich report on generational marketing. New York: Harper.

Stigler, G. J. (1961). The economics of information. Journal of Political Economy, 60(June), 213-225. 


\section{Appendix}

\section{Table 1: Purchase intention model}

\begin{tabular}{lcrl}
\hline Variable & Coefficient & $t$-Value and significance \\
\hline Intercept & 3.519 & 26.850 & $p$-value 0.000 \\
Sex $(+)$ & 0.199 & 3.529 & $p$-value 0.000 \\
Age $(-)$ & -0.310 & -17.561 & $p$-value 0.000 \\
Education (+) & 0.004 & 1.914 & $p$-value 0.056 \\
Income $(+)$ & 0.006 & 4.881 & $p$-value 0.000 \\
Adjusted $R$-square & 0.188 & & \\
F-value & 104.858 sig. 0.000 & & \\
\hline
\end{tabular}

$\mathrm{PI}=\beta_{0}+\beta_{1}$ sex $+\beta_{2}$ age $+\beta_{3}$ education $+\beta_{4}$ income $+\varepsilon$ 